\title{
Inhibitors of inflammation and endogenous surfactant pool size as modulators of lung injury with initiation of ventilation in preterm sheep
}

Noah H Hillman ${ }^{1 *}$, Suhas G Kallapur ${ }^{1,2}$, J Jane Pillow², llias Nitsos² ${ }^{2}$ Graeme R Polglase², Machiko Ikegami', Alan $\mathrm{H}$ Jobe $^{1,2}$

\begin{abstract}
Background: Increased pro-inflammatory cytokines in tracheal aspirates correlate with the development of BPD in preterm infants. Ventilation of preterm lambs increases pro-inflammatory cytokines and causes lung inflammation.

Objective: We tested the hypothesis that selective inhibitors of pro-inflammatory signaling would decrease lung inflammation induced by ventilation in preterm newborn lambs. We also examined if the variability in injury response was explained by variations in the endogenous surfactant pool size.

Methods: Date-mated preterm lambs $(n=28)$ were operatively delivered and mechanically ventilated to cause lung injury (tidal volume escalation to $15 \mathrm{~mL} / \mathrm{kg}$ by $15 \mathrm{~min}$ at age). The lambs then were ventilated with $8 \mathrm{~mL} / \mathrm{kg}$ tidal volume for $1 \mathrm{~h} 45 \mathrm{~min}$. Groups of animals randomly received specific inhibitors for IL-8, IL-1, or NF- $\kappa$ B. Unventilated lambs $(n=7)$ were the controls. Bronchoalveolar lavage fluid (BALF) and lung samples were used to quantify inflammation. Saturated phosphatidylcholine (Sat PC) was measured in BALF fluid and the data were stratified based on a level of $5 \mu \mathrm{mol} / \mathrm{kg}$ ( $\sim 8 \mathrm{mg} / \mathrm{kg}$ surfactant).

Results: The inhibitors did not decrease the cytokine levels or inflammatory response. The inflammation increased as Sat PC pool size in BALF decreased. Ventilated lambs with a Sat PC level $>5 \mu \mathrm{mol} / \mathrm{kg}$ had significantly decreased markers of injury and lung inflammation compared with those lambs with $<5 \mu \mathrm{mol} / \mathrm{kg}$.

Conclusion: Lung injury caused by high tidal volumes at birth were decreased when endogenous surfactant pool sizes were larger. Attempts to decrease inflammation by blocking IL-8, IL-1 or NF- $\kappa$ B were unsuccessful.
\end{abstract}

\section{Introduction}

Ventilation of preterm newborn lambs initiates inflammation in the lungs [1,2]. Like preterm sheep, ventilated very low birth weight (VLBW) infants have increased concentrations of the pro-inflammatory cytokines IL-8, IL-1 $\beta$, IL-6, and MCP-1 in tracheal aspirates and these increased levels correlate with an increased risk of bronchopulmonary dysplasia (BPD) [3-5]. Ventilation of preterm infants with moderate respiratory distress increased plasma levels of IL- $1 \beta$, IL- 8 and TNF- $\alpha$ and decreased levels of the anti-inflammatory cytokine IL-10 [6]. Surfactant is the major variable determining the

\footnotetext{
* Correspondence: Noah.Hillman@cchmc.org

${ }^{1}$ Cincinnati Children's Hospital Medical Center, Division of Pulmonary Biology, Cincinnati, OH, USA 45236

Full list of author information is available at the end of the article
}

compliance of the preterm lung [7], and surfactant treatment will decrease lung injury [8]. However the initiation of ventilation at birth is a unique situation because the airways initially are airless and fluid filled, and without labor, little surfactant will have been secreted into the fetal lung fluid. The initial ventilation of the preterm lung will occur before much of the endogenous surfactant is secreted [9], potentially increasing the risk of injury in a lung that might be protected by surfactant. The initiation of ventilation at birth stretches the airways and triggers early growth response protein 1 (Egr-1) activation [10]. The pro-inflammatory cascade from Egr-1 signals through NF- $\kappa \mathrm{B}$ to increase cytokines and chemokines $[1,10]$.

At a given preterm gestational age, infants have variable lung maturation because of the abnormalities 
associated with the preterm delivery. An argument for allowing the infant to transition to air breathing with continuous positive airway pressure (CPAP) is that uncontrolled high tidal volume ventilation can be avoided [11]. However, many infants will require ventilation to achieve respiratory transition [12]. The variability in lung function in experimental animals at delivery is less than in humans because the pregnancies are normal and the deliveries are carefully controlled. However, in sheep fetal lung maturation is rapidly changing between 128 and 136 days gestation [13]. We used a standardized 15 min escalating tidal volume injury maneuver in preterm sheep delivered at 133-134 d gestation to test if inhibitors of IL-8, IL- 1 , or NF- $\kappa$ B would decrease injury responses. We used well described early response genes (HSP70, Egr-1) and acute phase cytokines (IL-1 $\beta$, IL-6, IL-8, MCP-1), as well as inflammatory cells, to quantify the lung injury. We also evaluated the endogenous surfactant pool size to test how this variability modulated the standardized stretch injury.

\section{Methods}

The investigations were approved by the Animal Ethics Committees of the University of Western Australia and Cincinnati Children's Hospital Medical Center.

\section{Ventilation protocol}

Ewes at $133 \mathrm{~d}$ to $134 \mathrm{~d}$ gestation were anesthetized prior to operative delivery of lambs [2]. Following externalization of the head, an endotracheal tube was secured surgically [14]. After delivery, lambs were weighed and ventilated with heated and humidified gas with $\mathrm{FiO}_{2}$ of 0.4 , rate 40 breaths $/ \mathrm{min}$, and inspiration time of $0.7 \mathrm{sec}$ (Bournes BP200) without surfactant treatment. Lambs received ventilation without PEEP and with tidal volume $\left(\mathrm{V}_{\mathrm{T}}\right)$ targets of $8-10 \mathrm{~mL} / \mathrm{kg}$ at $5 \mathrm{~min}, 12 \mathrm{~mL} / \mathrm{kg}$ at 10 min, and $15 \mathrm{~mL} / \mathrm{kg}$ by $15 \mathrm{~min}$, followed by $1 \mathrm{~h} 45 \mathrm{~min}$ ventilation with a PEEP $5 \mathrm{cmH}_{2} \mathrm{O}$ and a target $\mathrm{PaCO}_{2}$ at 50-60 mmHg. The upper limits were $40 \mathrm{cmH}_{2} \mathrm{O}$ for PIP and $10 \mathrm{~mL} / \mathrm{kg}$ for $\mathrm{V}_{\mathrm{T}}$. $\mathrm{V}_{\mathrm{T}}$ values were measured continuously with Florian Respiratory Monitors (Acutronic Medical Systems, Switzerland). $\mathrm{FiO}_{2}$ was adjusted to maintain an oxyhemoglobin saturation between $88-95 \%$. The ventilated lambs had umbilical arterial and venous catheters placed, and were anesthetized with Remifentanil and Propofol [14]. The animals received a $\mathrm{FiO}_{2}$ of 1.0 for 3 minutes prior to receiving a lethal dose of intravenous pentobarbital $(100 \mathrm{mg} / \mathrm{kg})$ at $2 \mathrm{~h}$ after birth. Unventilated controls were euthanized prior to delivery.

\section{Treatment with inhibitors}

Lambs were randomized to selected inhibitors of inflammation ( $\mathrm{n}=7$ animals/group) given prior to delivery and prior to initiating high $\mathrm{V}_{\mathrm{T}}$ ventilation. Lambs were randomized to: 1) No inhibitor - received the $V_{\mathrm{T}}$ injury maneuver followed by ventilation only, 2) a NF- $\kappa$ B Inhibitor: Parthenolide $5 \mathrm{mg}$ IV and $5 \mathrm{mg}$ given intratracheally, mixed with the fetal lung fluid (Sigma, St. Louis, MO), 3) an IL-8 inhibitor: nicotinanilide thioglycolate methyl ester (NTME) $10 \mathrm{mg}$ IV (Synthrix Biosystems, Auburn, WA), 4) the IL-1 receptor antagonist: Anikinra at doses of $100 \mathrm{mg}$ IV and $100 \mathrm{mg}$ intratracheally (Amgen, Inc., Thousand Oaks, CA), or 5) unventilated controls. Doses and routes of administration for this pilot study were determined from prior experiments [15-17].

\section{Lung Processing and Analysis}

Bronchoalveolar lavage fluid (BALF) of the left lung was used to determine total protein content [18], saturated phosphatidylcholine (Sat PC) and differential cell counts after cytospins [19]. Sat PC was recovered after treatment of organic solvet extracts of the BALF with osmium tetroxide by alumina column chromatography and quantified by phosphorus assay [20]. Tissue from the lung were snap frozen. Total RNA was isolated using a modified Chomzynski method, and $10 \mu \mathrm{g}$ of total RNA was used for IL-1 $\beta$, IL-6, and IL-8 RNAse protection assays $[21,22]$. The right upper lobe was inflation fixed at $30 \mathrm{cmH}_{2} 0$ with $10 \%$ formalin [23], and tissue sections were used for injury scores [1]. MCP-1 protein from BALF was analyzed by sandwich ELISA using anti-ovine MCP-1 antibodies [24]. Immunostaining protocols used paraffin sections $(5 \mu \mathrm{m}$, transverse) of formalin fixed tissues with anti-human Egr-1 1:250 dilution (Santa Cruz, USA) or anti-ovine MCP-1 1:300 (internally produced) [1,2]. For HSP70 mRNA identification in situ, digoxigenin-labeled riboprobes were generated (Roche, USA) and developed per protocol [1].

\section{Statistics}

All values are expressed as means \pm SEM. Comparisons between intervention groups were made with two-tailed Mann-Whitney nonparametric tests, Welch t-tests, or ANOVA where appropriate. Significance was accepted at $\mathrm{p}<0.05$.

\section{Results}

All 28 lambs survived the $2 \mathrm{~h}$ ventilation period. There were no differences between cord blood gas measurements, birth weights, or gender between the groups. All animals achieved the $\mathrm{V}_{\mathrm{T}}$ goal of $15 \mathrm{~mL} / \mathrm{kg}$ by $15 \mathrm{~min}$ and animals had similar $V_{\mathrm{T}}$ ventilation throughout the 2 h study (Table 1). All ventilated lambs had increased BAL inflammatory cells, total protein, and MCP-1 protein compared with unventilated controls. There were no differences in the cytokine mRNA levels for IL- $1 \beta$, IL- 6 or IL- 8 between the untreated or the inhibitor 
Table 1 Animals grouped by inhibitor treatments

\begin{tabular}{|c|c|c|c|c|c|c|c|c|c|c|}
\hline & $\mathbf{N}$ & BW & $\begin{array}{l}V_{T} \\
15 \text { min }\end{array}$ & $\begin{array}{l}V_{T} \\
2 h\end{array}$ & BALF Protein & BALF Inflammatory cells & $\begin{array}{l}\text { BALF } \\
\text { MCP-1 }\end{array}$ & $\begin{array}{l}\text { IL-1 } \beta \\
\text { mRNA }\end{array}$ & $\begin{array}{l}\text { IL-6 } \\
\text { mRNA }\end{array}$ & $\begin{array}{l}\text { IL-8 } \\
\text { mRNA }\end{array}$ \\
\hline & & & \multicolumn{2}{|c|}{$\mathrm{mL} / \mathrm{kg}$} & $\mathrm{mg} / \mathrm{kg}$ & $x 10^{6} / \mathrm{kg}$ & $\mathrm{ng} / \mathrm{mL}$ & \multicolumn{3}{|c|}{ fold increase } \\
\hline Controls & 7 & $3.2 \pm 0.1$ & \multicolumn{2}{|c|}{ None } & $23 \pm 6$ & $1.2 \pm 1.0$ & $0.6 \pm 0.6$ & $1 \pm 0.2$ & $1 \pm 0.2$ & $1 \pm 0.1$ \\
\hline No Inhibitor & 7 & $3.5 \pm 0.2$ & $15.7 \pm 0.5$ & $8.6 \pm 0.8$ & $82 \pm 11^{*}$ & $81 \pm 23^{*}$ & $28 \pm 7^{*}$ & $16 \pm 4^{*}$ & $43 \pm 14^{*}$ & $28 \pm 12^{*}$ \\
\hline NF- $\kappa \mathrm{B}$ Inhbitor & 7 & $3.6 \pm 0.1$ & $16.2 \pm 1.1$ & $9.3 \pm 0.4$ & $92 \pm 18^{*}$ & $101 \pm 34^{*}$ & $44 \pm 10^{*}$ & $21 \pm 4^{*}$ & $53 \pm 11^{*}$ & $24 \pm 5^{*}$ \\
\hline IL-8 Inhibitor & 7 & $3.3 \pm 0.1$ & $15.5 \pm 1.4$ & $10.9 \pm 0.9$ & $72 \pm 11^{*}$ & $63 \pm 29^{*}$ & $32 \pm 13^{*}$ & $14 \pm 5^{*}$ & $20 \pm 7^{*}$ & $12 \pm 3^{*}$ \\
\hline IL-1 Inhibitor & 7 & $3.6 \pm 0.2$ & $16.4 \pm 0.7$ & $9.6 \pm 0.7$ & $72 \pm 18^{*}$ & $33 \pm 11^{*}$ & $13 \pm 7^{*}$ & $7 \pm 2^{*}$ & $23 \pm 15^{*}$ & $9 \pm 3^{*}$ \\
\hline
\end{tabular}

$\mathrm{BALF}=$ bronchoalveolar lavage fluid, $\mathrm{BW}=$ birth weight ${ }^{*} \mathrm{p}<0.05$ vs Controls.

treatment groups. The lambs at this gestational age had large differences in surfactant pool size as measured by Sat PC in the BALF. The wide variances for cytokine mRNA within each treatment group correlated with the variation of Sat PC pool sizes (Figure 1). When analyzed in this way, the inhibitors had no effect on the injury within the limits of group sizes of 7 animals.

Lambs then were stratified into two groups based on the graphical presentations noted in Figure 1 into those with Sat PC levels $<5 \mu \mathrm{mol} / \mathrm{kg}$ in BAL $(\mathrm{n}=18)$ and those with levels $>5 \mu \mathrm{mol} / \mathrm{kg}$ in BAL $(\mathrm{n}=10)$. Unventilated control lambs had a Sat PC level of $2.0 \pm 0.5$ $\mu \mathrm{mol} / \mathrm{kg}$. All lambs had less Sat PC than the normal levels of approximately $65 \mu \mathrm{mol} / \mathrm{kg}$ reported for term lambs [25]. There were no differences in birth weight, gestational age, or gender ratio between lambs with Sat $\mathrm{PC}$ values greater or less than $5 \mu \mathrm{mol} / \mathrm{kg}$ (Table 2). The differences in Sat PC measured at $2 \mathrm{~h}$ did not significantly change the dynamic compliance during the 15 $\min \mathrm{V}_{\mathrm{T}}$ injury maneuver (Table 2). Although no significant differences in $\mathrm{V}_{\mathrm{T}}$ or compliance were apparent during the $15 \mathrm{~min}$ stretch injury or at $30 \mathrm{~min}$, lambs with
Sat PC levels $>5 \mu \mathrm{mol} / \mathrm{kg}$ had improved ventilation, oxygenation, and compliances when ventilated with lower $\mathrm{V}_{\mathrm{T}}$ for the last hour of mechanical ventilation (Figure 2). Lambs with Sat $\mathrm{PC}<5 \mu \mathrm{mol} / \mathrm{kg}$ required a $\mathrm{FiO}_{2}$ between 0.40 to 0.53 to maintain oxygen saturations, whereas the lambs with higher Sat PC levels required a $\mathrm{FiO}_{2}$ of only 0.25 to 0.39 .

All markers of lung injury were higher in animals with Sat PC levels below $5 \mu \mathrm{mol} / \mathrm{kg}$ in BALF than in the animals with higher Sat PC levels (Table 2). All ventilated animals had airway injury with sloughing of epithelium and inflammatory cells. Injury scoring between groups was higher in low Sat PC animals (Table 2). In situ localization of HSP70 mRNA demonstrated loss of the mRNA from bronchial epithelial cells in the ventilated animals compared with the unventilated controls and increased HSP70 mRNA in the smooth muscle surrounding the airways with ventilation (Figure 3A-C). There were no differences in HSP70 mRNA expression, representing similar airway over-expansion during ventilation. Early growth response protein 1 (Egr-1) surrounded the mesenchyme of the larger airways and was

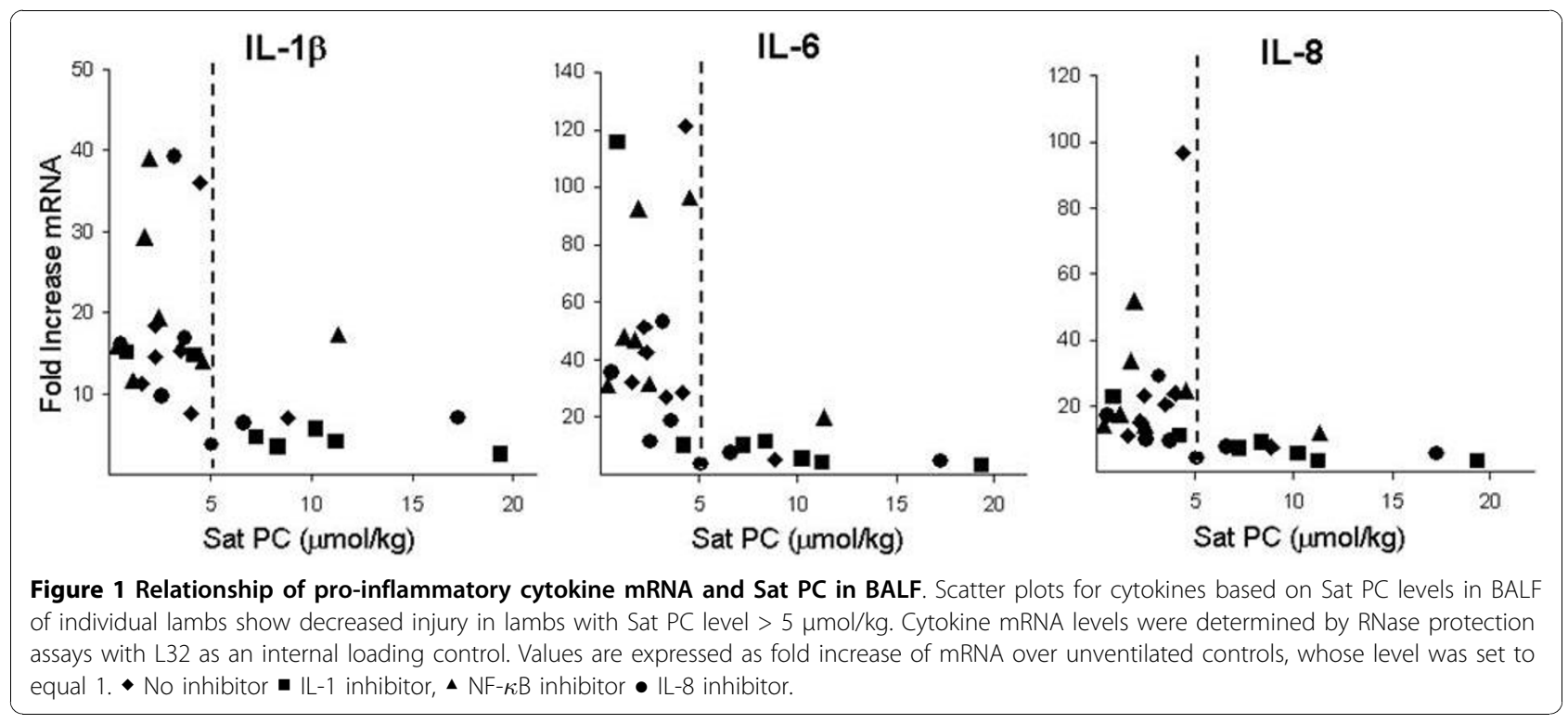


Table 2 Saturated phosphatidylcholine levels and indices of injury

\begin{tabular}{|c|c|c|c|}
\hline & $\begin{array}{c}\text { Sat } \mathrm{PC}< \\
5 \\
(\mathrm{n}=18)\end{array}$ & $\begin{array}{c}\text { Sat PC > } \\
5 \\
(n=10)\end{array}$ & $p$ value \\
\hline \multicolumn{4}{|l|}{ Description of Animals } \\
\hline Birth weight (kg) & $3.5 \pm 0.1$ & $3.5 \pm 0.1$ & $=1$ \\
\hline Gender (male:female) & $10: 8$ & $6: 4$ & $=1$ \\
\hline Gestational Age (days) & 133.1 & 133.1 & $=1$ \\
\hline BAL Sat PC $(\mu \mathrm{mol} / \mathrm{kg})$ & $2.5 \pm 0.3$ & $\begin{array}{c}10.6 \pm \\
1.4^{*}\end{array}$ & $<0.001$ \\
\hline \multicolumn{4}{|l|}{$\mathrm{V}_{\mathrm{T}}$ and Compliance } \\
\hline $\mathrm{V}_{\mathrm{T}} / \mathrm{kg}$ at $5 \mathrm{~min}(\mathrm{~mL} / \mathrm{kg})$ & $10.2 \pm 0.6$ & $10.8 \pm 0.7$ & $=1$ \\
\hline $\mathrm{V}_{\mathrm{T}} / \mathrm{kg}$ at $10 \mathrm{~min}(\mathrm{~mL} / \mathrm{kg})$ & $14.4 \pm 0.4$ & $14.3 \pm 0.5$ & $=1$ \\
\hline $\mathrm{V}_{\mathrm{T}} / \mathrm{kg}$ at $15 \mathrm{~min}(\mathrm{~mL} / \mathrm{kg})$ & $15.6 \pm 0.6$ & $16.5 \pm 0.5$ & $=1$ \\
\hline $\begin{array}{l}\text { Compliance } 5 \mathrm{~min}\left(\mathrm{~mL} / \mathrm{cmH}_{2} \mathrm{O} /\right. \\
\mathrm{kg})\end{array}$ & $\begin{array}{c}0.28 \pm \\
0.02\end{array}$ & $\begin{array}{l}0.31 \pm \\
0.03\end{array}$ & $=0.50$ \\
\hline $\begin{array}{l}\text { Compliance } 10 \mathrm{~min}\left(\mathrm{~mL} / \mathrm{cmH}_{2} \mathrm{O} /\right. \\
\mathrm{kg})\end{array}$ & $\begin{array}{c}0.34 \pm \\
0.01\end{array}$ & $\begin{array}{c}0.39 \pm \\
0.02\end{array}$ & $=0.11$ \\
\hline $\begin{array}{l}\text { Compliance } 15 \mathrm{~min}\left(\mathrm{~mL} / \mathrm{cmH}_{2} \mathrm{O} /\right. \\
\mathrm{kg})\end{array}$ & $\begin{array}{c}0.36 \pm \\
0.02\end{array}$ & $\begin{array}{c}0.42 \pm \\
0.02\end{array}$ & $=0.06$ \\
\hline \multicolumn{4}{|l|}{ BAL Fluid } \\
\hline Protein $(\mathrm{mg} / \mathrm{kg})$ & $94.4 \pm 9.0$ & $52.4 \pm 7.8$ & $<0.002$ \\
\hline Neutrophils $\left(\times 10^{6} / \mathrm{kg}\right)$ & $74.2 \pm 1.8$ & $16.2 \pm 9.6$ & $<0.01$ \\
\hline Monocytes (x10\%/kg) & $12.3 \pm 2.9$ & $8.9 \pm 1.3$ & $=0.49$ \\
\hline MCP-1 protein $(\mathrm{ng} / \mathrm{ml})$ & $42.1 \pm 5.6$ & $7.2 \pm 3.2$ & $\begin{array}{l}< \\
0.0001\end{array}$ \\
\hline \multicolumn{4}{|l|}{ Lung Tissue (mRNA fold increase) } \\
\hline $\mathrm{IL}-1 \beta$ & $19.2 \pm 2.3$ & $6.2 \pm 1.3$ & $\begin{array}{l}< \\
0.0001\end{array}$ \\
\hline IL-6 & $49.9 \pm 8.0$ & $7.2 \pm 1.8$ & $<0.001$ \\
\hline IL-8 & $24.8 \pm 4.8$ & $6.7 \pm 0.8$ & $\begin{array}{l}< \\
0.0001\end{array}$ \\
\hline
\end{tabular}

Injury Scores

(Out of 8 total points)

$4.8 \pm 0.2 \quad 3.0 \pm 0.5 \quad=0.02$

$\mathrm{V}_{\mathrm{T}}=$ tidal volume, $\mathrm{BAL}=$ bronchoalveolar lavage fluid, Sat $\mathrm{PC}=$ saturated phosphatidylchloline.

$\mathrm{BW}=$ birth weight, Compliance $=(\mathrm{VT} / \mathrm{kg}) /(\mathrm{PIP}-\mathrm{PEEP}) * \mathrm{p}<0.05$ vs Sat $\mathrm{PC}<5$

expressed in the medium sized conducting airways (Figure $3 \mathrm{D}-\mathrm{F}$ ). Egr-1 staining tended to be higher (175 vs 128 cells/high power field) in animals with lower Sat PC levels (Figure 3D-F). MCP-1 protein was localized to similar regions, but with more variation within each group (Figure 3G-I). MCP-1 protein levels in the BAL were increased 5 fold in animals with Sat PC less than 5 $\mu \mathrm{mol} / \mathrm{kg}$ (Table 2).

\section{Discussion}

Using a premature sheep model, we mimicked high tidal volume resuscitation with subsequent ventilation to test if several inhibitors of pro-inflammatory mediators would decrease injury. The preterm lambs had lung inflammation to 15 minutes of escalating $\mathrm{V}_{\mathrm{T}}$ ventilation and the subsequent ventilation. Although the study was designed to cause lung injury, the current preterm lambs had a similar magnitude increase in inflammatory markers to lambs ventilated with a tidal volume of 8 $\mathrm{mL} / \mathrm{kg}$ and PEEP of $5 \mathrm{cmH}_{2} \mathrm{O}$ [14]. We did not find differences in respiratory physiology or markers of injury between the ventilation only animals and those treated with inhibitors of IL-1, IL-8, or NF- $\kappa$ B, but there was variable injury within each treatment group. We took advantage of this variable injury to demonstrate that the amount of Sat PC in the BALF at autopsy was associated with the amount of lung inflammation and injury. There appears to be a critical surfactant threshold (approximately $5 \mu \mathrm{mol} / \mathrm{kg}$ in preterm lambs) for partial protection of the preterm lung from injury and inflammation caused by initiation of ventilation with high $\mathrm{V}_{\mathrm{T}}$. However the surfactant pool size measured at $2 \mathrm{~h}$ did not correlate with the compliances of the animals during the initial 15 min ventilation injury.

In these studies, we attempted to inhibit important pro-inflammatory mediators of early lung injury response. Since many of the pro-inflammatory cytokines are transcribed after nuclear translocation of NF- $\kappa \mathrm{B}$, we used both IV and intra-tracheal parthenolide to block NF-kB activation in 7 lambs. Parthenolide is a sesquiterpene lactone derived from the plant Feverfew which may block NF- $\kappa \mathrm{B}$ activity through inhibition of $\mathrm{I} \kappa-\mathrm{B}$ kinase activity [26]. The NF-kB system is active in preterm sheep and responds to intra-amniotic LPS [27]. Mice also have NF- $\kappa \mathrm{B}$ activity by mid-gestation which increases near the end of gestation and in early postnatal life [28]. Mice ventilated with large $V_{T}$ had NF- $\kappa B$ activation and cytokine production similar to mice exposed to LPS, but the cytokine increases were blocked by pretreatment with dexamthasone [29]. Our previous attempts to block lung inflammation with high dose dexamethasone or hydrocortisone were unsuccessful in the setting of initiation of ventilation in preterm sheep [2]. In a newborn piglet model of RDS, animals receiving a NF- $\kappa \mathrm{B}$ inhibitor had no improvement over controls [30]. Inhibition of NF- $\kappa \mathrm{B}$ in mice exposed to high $\mathrm{V}_{\mathrm{T}}$ ventilation and hyperoxia blocked the additive effect of hyperoxia on volutrauma suggesting differing roles of $\mathrm{NF}-\kappa \mathrm{B}$ in stretch injury verses oxidative injury [31]. In these three animal models of acute respiratory failure and in these preterm lambs, blockade of NF- $\kappa \mathrm{B}$ was unable to prevent inflammation from mechanical ventilation.

We also attempted to block two of the major proinflammatory cytokines that are increased with high $\mathrm{V}_{\mathrm{T}}$ ventilation. We used recombinant human IL-1ra (Anikinra) to block IL-1 signaling. rhIL-RA is used clinically for treatment of a variety of inflammatory diseases and mutations ofIL-1ra result in severe systemic 

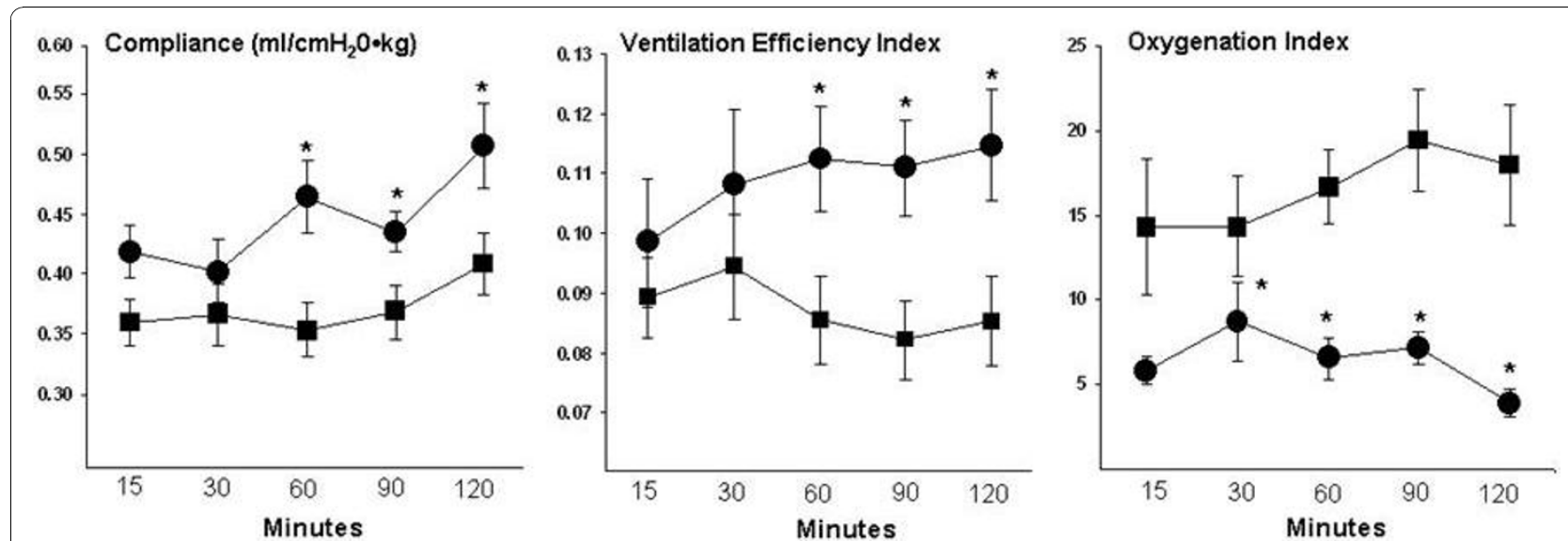

Figure 2 Compliance, ventilation efficiency index, and oxygenation. Lambs with Sat $P C<5 \mu \mathrm{mol} / \mathrm{kg}$ had decreased dynamic compliance values for the last hour of ventilation. Ventilation efficiency index decreased and oxygenation index increased in lambs with Sat $P C<5 \mu \mathrm{mol} / \mathrm{kg}$, indicating decreased gas exchange over time. Oxygenation index at $2 \mathrm{~h}$ was measured on an $\mathrm{FiO}_{2}$ of 1.0. Compliance $=\mathrm{V}_{\mathrm{T}} /$ pressure, Ventilation Efficiency Index $=3800 /\left(\mathrm{PIP} \cdot r a t e \cdot \mathrm{PaCO}_{2}\right)$. Oxgenation index $=\left(\mathrm{FiO}_{2} \cdot\right.$ Mean Airway pressure $) / \mathrm{PaO}_{2}$ • Sat $\mathrm{PC}>5 \mu \mathrm{mol} / \mathrm{kg}$ - Sat PC $<5 \mu \mathrm{mol} / \mathrm{kg} * \mathrm{p}$ $<0.05$ vs Sat $P C<5 \mu \mathrm{mol} / \mathrm{kg}$.

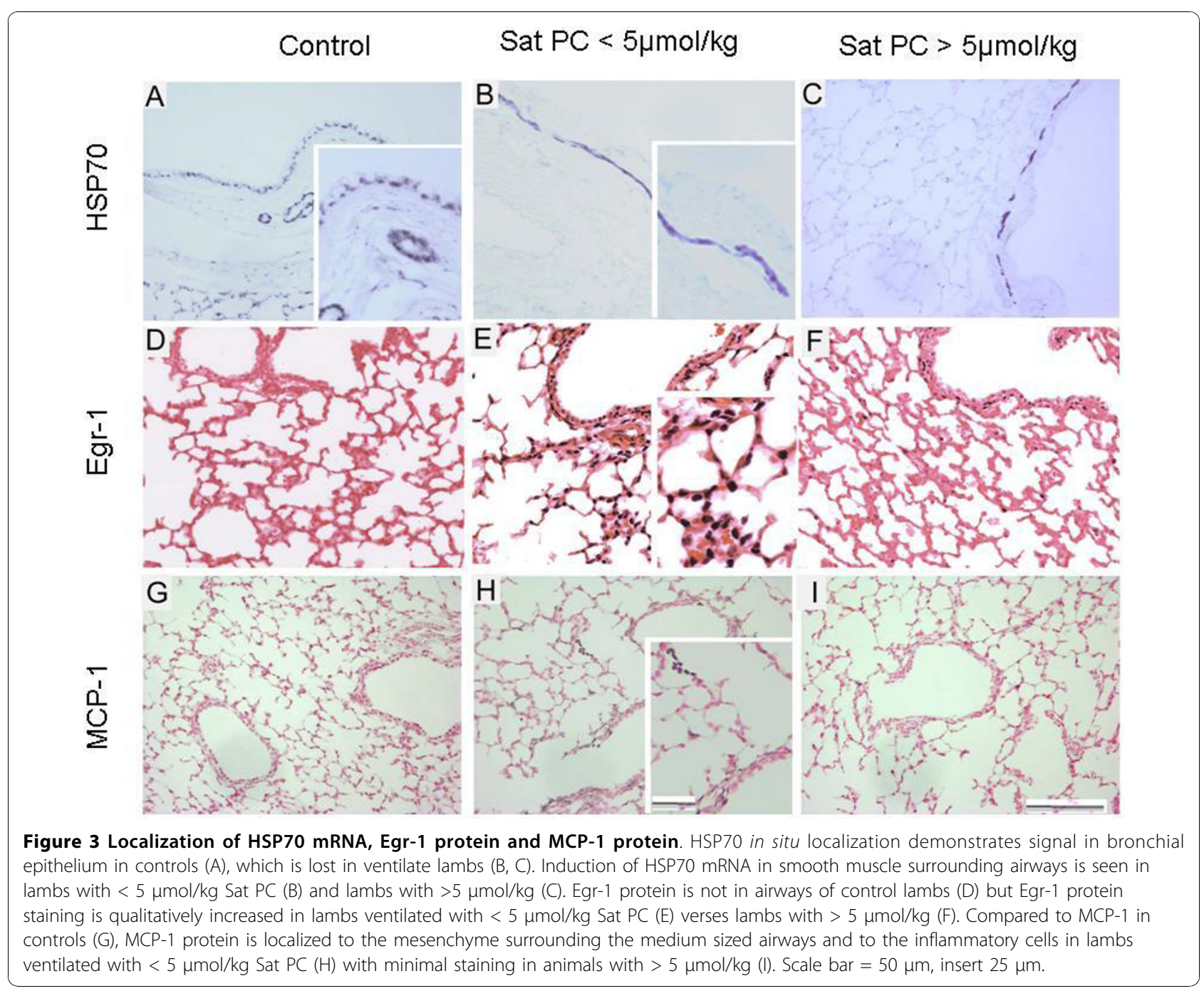


inflammation in early childhood [32]. We previously demonstrated that rhIL-1ra completely blocked lung inflammation from recombinant sheep IL-1 and decreased, but did not eliminate, the inflammatory response to LPS [16]. When adjusted for the amount of Sat PC in BAL, the IL-1 receptor blocker did not decrease lung injury in these lambs. We also tested nicotinanilide thioglycolate methyl ester (NTME), a CXCR2 inhibitor, to block IL-8 signaling. We previously demonstrated that NTME blocked recombinant ovine IL-8, but did not inhibitLPS induced lung inflammation in preterm sheep [15]. We found no decrease in ventilation mediated lung injury for this IL-8 inhibitor. Although drug levels were not measured in this study, we previously measured bio-availability of Anikinra and NTME in sheep $[15,16]$. Based on our previous results, the dosage used in the present study should have blocked IL-1 and IL-8 signaling. These studies, in combination with our previous study with postnatal corticosteroid treatment, suggest that blockade of proinflammatory responses to the initiation of ventilation of preterm infants will not be accomplished easily.

Previous preterm animal studies demonstrated improved ventilation with increasing endogenous surfactant pool sizes $[7,19]$. Base on the observation that animals with lower Sat PC levels had exponentially higher indicators of lung injury, we stratified the animals based on Sat PC level. We found animals with Sat PC levels less than $<5 \mu \mathrm{mol} / \mathrm{kg}$ (about $8 \mathrm{mg} / \mathrm{kg}$ surfactant based on assumption that Sat PC is $50 \%$ of the surfactant lipid pool) had significantly more injury than those with more Sat PC. These findings were similar to our previous findings that lambs with less than $1.9 \mu \mathrm{mol} / \mathrm{kg}$ Sat PC (3 $\mathrm{mg} / \mathrm{kg}$ surfactant) had high $\mathrm{PaCO}_{2}$ on CPAP, whereas lambs with more Sat PC had normal $\mathrm{PaCO}_{2}$ levels [19]. The average surfactant pool of the term newborn sheep is approximately $100 \mathrm{mg} / \mathrm{kg}$ in BALF [25]. The average surfactant pool in group of animals with $>5 \mu \mathrm{mol} / \mathrm{kg}$ was about $15 \%$ of the levels reported at term. The average Sat PC pool for the lambs with $<5 \mu \mathrm{mol} / \mathrm{kg}$ was $2.5 \mu \mathrm{mol} / \mathrm{kg}$, about 1.3 fold higher than that for lambs that previously survived on CPAP [19]. This lower effective pool size for the lambs on CPAP may result from the lack of intentional lung injury in those animals. The high $V_{T}$ and resultant lung injury should cause inhibition of endogenous surfactant pools [7]. In 1970, Adams found surfactant pools less than $5 \mathrm{mg} / \mathrm{kg}$ in infants who died with RDS without mechanical ventilation [33]. These lambs were date-mated and the majority of lambs $(25 / 28)$ were 133 days gestation, suggesting that small variations in lung maturation at the same gestational age can affect lung injury. Small changes in endogenous surfactant levels may have larger effects on lung mechanics than larger surfactant pool size increases with surfactant treatment [7].

Small increases in the endogenous surfactant pool size could decrease the heterogeneity of lung expansion and cause a more even distribution of $\mathrm{V}_{\mathrm{T}}$ across the regions of the lung, and thus decrease focal injury [34]. Surfactant decreases surface tension and maintains FRC [35]. Since no PEEP was used during the first $15 \mathrm{~min}$, the lambs with higher Sat PC may have had reduced regions of airway collapse. Newly secreted surfactant following birth is the large aggregate surfactant that has the best functional characteristics. High tidal volume ventilation can convert surfactant from surface-active large-aggregates to less surface-active surfactant forms [36] and these changes in surfactant forms proceed physiologic changes during ventilation [37]. The lambs with less surfactant in BAL may have had less functional surfactant and more surfactant inhibition, although these variables were not measured [38]. The induction of HSP70 in the smooth muscle of the airways was not changed by the amount of Sat PC, demonstrating an airway injury response with ventilation in all groups [1]. Our current analysis of injury based on surfactant pool size stresses the importance of the endogenous surfactant pool size on lung injury induced by the initiation of ventilation at birth.

A limitation of our study is the sample size ( $\mathrm{n}=7$ to 8 ) for each intervention group. The study is thus powered to demonstrate only large differences between inhibitor groups and small differences from the inhibitors would not be detected. This variability in injury response is a limitation to studies with large animals. Another limitation of the study is the use of Sat PC levels after 2 hours of ventilation as a marker for endogenous surfactant pool size at birth. Surfactant is secreted into the airspace with the initiation of ventilation [9], such the pool size during the 15 min of tidal volume escalation would be smaller than the values measured at $2 \mathrm{hr}$. A final limitation of large animal studies is the difficulty in proving causality. We simply can correlate the results that lambs with increased surfactant pool sizes had decreased injury, as was seen with premature rabbits [13].

\section{Conclusions}

Small changes in the surfactant pool size correlated with large differences in lung injury and inflammation. All the preterm lambs were surfactant deficient and had ventilator induced lung injury, but a Sat PC level of $>5$ $\mu \mathrm{mol} / \mathrm{kg}$ was sufficient to reduce the injury. Stretch injury to preterm sheep lung activates multiple, overlapping acute phase response pathways, with cytokine production and lung inflammation as potential adverse outcomes. The lung inflammation from mechanical ventilation will likely not be prevented by the inhibition of any particular pro-inflammatory cytokine or by a more 
global inhibition with postnatal steroids [2]. While surfactant pools may serve as a biomarker for eventual lung injury from mechanical ventilation, there is no practical way to measure the pool size prior to or shortly after resuscitation in infants. Minor changes in surfactant pool sizes, as demonstrated by this study, are important for lung injury and support the use of antenatal steroids to increase surfactant.

\section{Abbreviations}

BALF: Bronchoalveolar lavage fluid; BPD: Bronchopulmonary dysplasia; Egr-1: Early growth response protein 1; HSP70: Heat Shock protein 70; MCP-1: Monocyte chemotactic protein 1; NF- $\kappa$ B: Nuclear factor kappa B; PEEP: Positive End Expiratory Pressure; PIP: Peak Inspiratory Pressure; Sat PC: Saturated phosphatidylcholine; VEl: Ventilator Efficiency Index; $V_{T}$ :Tidal Volume

\section{Acknowledgements}

This work was supported by grant NIH HD-12714 (AHJ), NIH K08HL 097085 $(\mathrm{NH})$, a Viertel Senior Medical Research Fellowship (JJP), a NHFA/NHMRC Fellowship (GRP), the Women and Infants Research Foundation and Fisher \& Paykel Healthcare, Auckland, NZ. The authors would like to thank Megan McAuliffe and Amy Whitescarver for their assistance in laboratory.

\section{Author details}

${ }^{1}$ Cincinnati Children's Hospital Medical Center, Division of Pulmonary Biology, Cincinnati, OH, USA 45236. '2School of Women's and Infants' Health, The University of Western Australia, Perth, WA, Australia 6009.

\section{Authors' contributions}

$\mathrm{NHH}$ did the animals studies, the molecular analysis, statistical analysis and drafted the manuscript. SGK did research design, molecular analysis and manuscript development. JJP did animal care and manuscript development. IN and GRP did animal breeding and manuscript development. MI did saturation PC analysis and manuscript editing. AHJ conceived the study, participated in its design, and help draft the manuscript. All authors have read and approve the manuscript.

\section{Competing interests}

The authors declare they have no competing interests to declare.

Received: 30 April 2010 Accepted: 29 October 2010

Published: 29 October 2010

\section{References}

1. Hillman NH, Kallapur SG, Pillow JJ, Moss TJ, Polglase GR, Nitsos I, Jobe AH: Airway injury from initiating ventilation in preterm sheep. Pediatr Res 2009, 67(1):60-65.

2. Hillman NH, Pillow JJ, Ball MK, Polglase GR, Kallapur SG, Jobe AH: Antenatal and postnatal corticosteroid and resuscitation induced lung injury in preterm sheep. Respiratory Research 2009, 10:124.

3. Kotecha S, Chan B, Azam N, Silverman M, Shaw RJ: Increase in interleukin8 and soluble intercellular adhesion molecule-1 in bronchoalveolar lavage fluid from premature infants who develop chronic lung disease. Archives of disease in childhood 1995, 72(2):F90-96.

4. Kotecha S, Wilson L, Wangoo A, Silverman M, Shaw RJ: Increase in interleukin (IL)-1 $\beta$ and IL-6 in bronchoalveolar lavage fluid obtained from infants with chronic lung disease of prematurity. Pediatr Res 1996, 40(2):250-256

5. Baier RJ, Majid A, Parupia H, Loggins J, Kruger TE: CC chemokine concentrations increase in respiratory distress syndrome and correlate with development of bronchopulmonary dysplasia. Pediatric Pulmonology 2004, 37(2):137-148.

6. Bohrer B, Silveira RC, Neto EC, Procianoy RS: Mechanical ventilation of newborns infant changes in plasma pro- and anti-inflammatory cytokines. The Journal of Pediatrics 156(1):16-19.
7. Ikegami M, Jobe AH, Yamada T, Seidner S: Relationship between alveolar saturated phosphatidylcholine pool sizes and compliance of preterm rabbit lungs. The effect of maternal corticosteroid treatment. The American Review of Respiratory Disease 1989, 139(2):367-369.

8. Wada $\mathrm{K}$, Jobe $\mathrm{AH}$, Ikegami M: Tidal volume effects on surfactant treatment responses with the initiation of ventilation in preterm lambs. J Appl Physiol 1997, 83(4):1054-1061.

9. Jacobs $H$, Jobe $A$, lkegami M, Jones S: Accumulation of alveolar surfactant following delivery and ventilation of premature lambs. Exp Lung Res 1985, 8(2-3):125-140

10. Wallace MJ, Probyn ME, Zahra VA, Crossley K, Cole TJ, Davis PG, Morley CJ, Hooper SB: Early biomarkers and potential mediators of ventilationinduced lung injury in very preterm lambs. Respiratory Research 2009, 10:19.

11. Morley CJ, Davis PG, Doyle LW, Brion LP, Hascoet JM, Carlin JB: Nasal CPAP or intubation at birth for very preterm infants. The New England Journal of Medicine 2008, 358(7):700-708.

12. Ammari A, Suri MS, Milisavljevic V, Sahni R, Bateman DA, Sanocka U, RuzalShapiro C, Wung JT, Polin RA: Variables associated with the early failure of nasal CPAP in very low birth weight infants. Journal of Pediatrics 2005, 147:341-347.

13. Jobe $A H$, Ikegami $M$, Jacobs $H C$, Jones SJ: Surfactant pool sizes and severity of respiratory distress syndrome in prematurely delivered lambs. The American review of respiratory disease 1983, 127(6):751-755.

14. Polglase GR, Hillman NH, Pillow JJ, Cheah FC, Nitsos I, Moss TJ, Kramer BW, Ikegami M, Kallapur SG, Jobe AH: Positive end-expiratory pressure and tidal volume during initial ventilation of preterm lambs. Pediatr Res 2008, 64(5):517-522.

15. Kallapur SG, Moss TJ, Auten RL, Nitsos I, Pillow JJ, Kramer BW, Maeda DY, Newnham JP, Ikegami M, Jobe AH: IL-8 signaling does not mediate intraamniotic LPS-induced inflammation and maturation in preterm fetal lamb lung. Am J Physiol 2009, 297(3):L512-519.

16. Kallapur SG, Nitsos I, Moss TJ, Polglase GR, Pillow JJ, Cheah FC, Kramer BW, Newnham JP, Ikegami M, Jobe AH: IL-1 mediates pulmonary and systemic inflammatory responses to chorioamnionitis induced by lipopolysaccharide. American journal of respiratory and critical care medicine 2009, 179(10):955-961.

17. Sheehan M, Wong HR, Hake PW, Malhotra V, O'Connor M, Zingarelli B: Parthenolide, an inhibitor of the nuclear factor-kappaB pathway, ameliorates cardiovascular derangement and outcome in endotoxic shock in rodents. Mol Pharmacol 2002, 61(5):953-963.

18. Lowry OH, Rosebrough NJ, Farr AL, Randall RJ: Protein measurement with the Folin phenol reagent. J Biol Chem 1951, 193(1):265-275.

19. Mulrooney N, Champion Z, Moss TJ, Nitsos I, Ikegami M, Jobe AH: Surfactant and Physiological Responses of Preterm Lambs to Continuous Positive Airway Pressure. American journal of respiratory and critical care medicine 2005, 171:1-6.

20. Kallapur SG, Willet KE, Jobe AH, Ikegami M, Bachurski C: Intra-amniotic endotoxin: Chorioamnionitis precedes lung maturation in preterm lambs. Am J Physiol 2001, 280:L527-L536.

21. Kallapur SG, Willet KE, Jobe AH, lkegami M, Bachurski CJ: Intra-amniotic endotoxin: chorioamnionitis precedes lung maturation in preterm lambs. Am J Physiol Lung Cell Mol Physiol 2001, 280(3):L527-536.

22. Hillman NH, Moss TJ, Nitsos I, Kramer BW, Bachurski CJ, Ikegami M, Jobe AH, Kallapur SG: Toll-like receptors and agonist responses in the developing fetal sheep lung. Pediatr Res 2008, 63(4):388-393.

23. Kramer BW, Moss TJ, Willet KE, Newnham JP, Sly PD, Kallapur SG, Ikegami M, Jobe AH: Dose and time response after intraamniotic endotoxin in preterm lambs. Am J Respir Crit Care Med 2001, 164(6):982-988.

24. Shah TAHN, Nitsos I, Polglase GR, Pillow JJ, Newnham JP, Jobe AH, Kallapur SG: Pulmonary and Systemic Expression of Monocyte Chemotactic Proteins in Preterm Sheep Fetuses Exposed to LPS Induced Chorioamnionitis. Pediatr Res 2010, 68(3):210-5.

25. Glatz T, Ikegami M, Jobe A: Metabolism of exogenously administered natural surfactant in the newborn lamb. Pediatr Res 1982, 16:711-715.

26. Saadane A, Masters S, DiDonato J, Li J, Berger M: Parthenolide inhibits IkappaB kinase, NF-kappaB activation, and inflammatory response in cystic fibrosis cells and mice. American journal of respiratory cell and molecular biology 2007, 36(6):728-736. 
27. Cheah FC, Pillow JJ, Kramer BW, Polglase GR, Nitsos I, Newnham JP, Jobe AH, Kallapur SG: Airway inflammatory cell responses to intraamniotic lipopolysaccharide in a sheep model of chorioamnionitis. Am J Physiol 2009, 296(3):L384-393.

28. Dohlen G, Odland HH, Carlsen H, Blomhoff R, Thaulow E, Saugstad OD: Antioxidant activity in the newborn brain: a luciferase mouse model. Neonatology 2008, 93(2):125-131.

29. Held HD, Boettcher S, Hamann L, Uhlig S: Ventilation-induced chemokine and cytokine release is associated with activation of nuclear factorkappaB and is blocked by steroids. American journal of respiratory and critical care medicine 2001, 163(3 Pt 1):711-716.

30. von Bismarck P, Klemm K, Garcia Wistadt CF, Winoto-Morbach S, Schutze S, Krause MF: Selective NF-kappaB inhibition, but not dexamethasone, decreases acute lung injury in a newborn piglet airway inflammation model. Pulmonary pharmacology \& therapeutics 2009, 22(4):297-304.

31. Liu YY, Liao SK, Huang CC, Tsai YH, Quinn DA, Li LF: Role for nuclear factor-kappaB in augmented lung injury because of interaction between hyperoxia and high stretch ventilation. Trans/ Res 2009, 154(5):228-240.

32. Aksentijevich I, Masters SL, Ferguson PJ, Dancey P, Frenkel J, van RoyenKerkhoff A, Laxer R, Tedgard U, Cowen EW, Pham TH, et al: An autoinflammatory disease with deficiency of the interleukin-1-receptor antagonist. The New England Journal of Medicine 2009, 360(23):2426-2437.

33. Adams FH, Fujiwara T, Emmanouilides GC, Raiha N: Lung phospholipid of the human fetus and infants with and without hyaline membrane disease. Journal of Pediatrics 1970, 77:833.

34. Jobe AH, Hillman N, Polglase G, Kramer BW, Kallapur S, Pillow J: Injury and inflammation from resuscitation of the preterm infant. Neonatology 2008, 94(3):190-196.

35. Scarpelli EM, Mautone AJ, DeFouw DO, Clutario BC: Intraalveolar bubbles and bubble films: II. Formation in vivo through adulthood. The Anatomical record 1996, 246(2):245-270.

36. Veldhuizen RAW, Marcou J, Yao $L$, et al: Alveolar surfactant aggregate conversion in ventilated normal and injured rabbits. Am J Physiol 1996, 14:152-158.

37. Maruscak AA, Vockeroth DW, Girardi B, Sheikh T, Possmayer F, Lewis JF, Veldhuizen RA: Alterations to surfactant precede physiological deterioration during high tidal volume ventilation. Am J Physiol 2008, 294(5):L974-983.

38. Michna J, Jobe AH, Ikegami M: Positive end-expiratory pressure preserves surfactant function in preterm lambs. American journal of respiratory and critical care medicine 1999, 160(2):634-639.

doi:10.1186/1465-9921-11-151

Cite this article as: Hillman et al: Inhibitors of inflammation and endogenous surfactant pool size as modulators of lung injury with initiation of ventilation in preterm sheep. Respiratory Research 2010 11:151.

\section{Submit your next manuscript to BioMed Central and take full advantage of:}

- Convenient online submission

- Thorough peer review

- No space constraints or color figure charges

- Immediate publication on acceptance

- Inclusion in PubMed, CAS, Scopus and Google Scholar

- Research which is freely available for redistribution 